Article

\title{
In Vitro Antioxidant and Antiproliferative Activities of Methanolic Plant Part Extracts of Theobroma cacao
}

\author{
Zainal Baharum ${ }^{1,2, *}$, Abdah Md Akim ${ }^{1}$, Yun Hin Taufiq-Yap ${ }^{3}$, Roslida Abdul Hamid ${ }^{1}$ \\ and Rosmin Kasran ${ }^{2}$
}

1 Department of Biomedical Science, Faculty of Medicine and Health Sciences, University Putra Malaysia, 43400 Serdang, Selangor, Malaysia; E-Mails: abdah@upm.edu.my (A.M.A.); roslida@upm.edu.my (R.A.H.)

2 Division of Biotechnology, Centre for Cocoa Biotechnology Research, Malaysian Cocoa Board, Commercial Zone 1, North KKIP, Norowot Road, 88460 Kota Kinabalu Industrial Park, Sabah, Malaysia; E-Mail: rosmin@koko.gov.my

3 Department of Chemistry, Faculty of Science, University Putra Malaysia, 43400 Serdang, Selangor, Malaysia; E-Mail: taufiq@upm.edu.my

* Author to whom correspondence should be addressed; E-Mail: zainal@koko.gov.my; Tel.: +60-6799-9004; Fax: +60-6794-1910.

External Editor: Isabel C. F. R. Ferreira

Received: 10 September 2014; in revised form: 16 October 2014 / Accepted: 17 October 2014/ Published: 10 November 2014

\begin{abstract}
The aims of this study were to determine the antioxidant and antiproliferative activity of the following Theobroma cacao plant part methanolic extracts: leaf, bark, husk, fermented and unfermented shell, pith, root, and cherelle. Antioxidant activity was determined using 2,2-diphenyl-2-picrylhydrazyl (DPPH), thiobarbituric acid-reactive substances (TBARS), and Folin-Ciocalteu assays; the 3-[4,5-dimethylthiazol-2-yl]-2,5diphenyltetrazolium (MTT) assay was used to determine antiproliferative activity. The root extract had the highest antioxidant activity; its median effective dose (EC50) was $358.3 \pm 7.0 \mu \mathrm{g} / \mathrm{mL}$ and total phenolic content was $22.0 \pm 1.1 \mathrm{~g} \mathrm{GAE} / 100 \mathrm{~g}$ extract as compared to the other methanolic plant part extracts. Only the cherelle extract demonstrated $10.4 \% \pm 1.1 \%$ inhibition activity in the lipid peroxidation assay. The MTT assay revealed that the leaf extract had the highest antiproliferative activity against MCF-7 cells [median inhibitory concentration $\left.\left(\mathrm{IC}_{50}\right)=41.4 \pm 3.3 \mu \mathrm{g} / \mathrm{mL}\right]$. Given the overall high $\mathrm{IC}_{50}$ for the normal liver cell line WRL-68, this study indicates that $T$. cacao methanolic extracts have a
\end{abstract}


cytotoxic effect in cancer cells, but not in normal cells. Planned future investigations will involve the purification, identification, determination of the mechanisms of action, and molecular assay of T. cacao plant extracts.

Keywords: Theobroma cacao; plant; antiproliferative; antioxidant; phenolics; natural product

\section{Introduction}

Cancer is a complex multifactorial cell disease characterized by abnormal cellular proliferation. Cancer development and progression are dependent on the cellular accumulation of various genetic and epigenetic events [1,2], and is an aberrant net accumulation of typical cells arising from excess proliferation, insufficient apoptosis, or a combination thereof [3]. Cancer development is normally caused by oncogene, tumor suppressor gene, and microRNA gene alterations [4]. It imposes a serious burden on the public health system, and its treatment and cure are scientifically challenging. Cancer is expected to claim nine million lives worldwide by 2015 [5]. In Malaysia, cancer is the fourth leading cause of death; it is the second leading cause of death in developed countries after cardiovascular diseases. The Ministry of Health of Malaysia has reported that deaths from breast cancer rank among the top 10 cancer-related deaths in the country. Currently, about $65 \%$ of drugs used in chemotherapy are of natural origin [6]. Medicinal plants have a long history in both traditional and modern cancer treatments [7,8] and have been used to treat human diseases for centuries [9-11]. Thus, it is possible that traditional medicinal plants can serve as potential sources for developing new drugs and more effective anti-cancer agents for future therapy [12].

Theobroma cacao (T. cacao) or cocoa, was considered a divine food by the Olmec, Maya, and Aztec civilizations that consumed its products as early as $600 \mathrm{BC}$. Several documents, among them the Badianus Manuscript, the Florentine Codex, and the Princeton Codex, show over 100 documented medicinal uses for cocoa. More than 200 studies have reported the bioactive compounds, chemical composition, and health benefits of cocoa and cocoa products [13-15]. Mhd. Jalil and Ismail [16] reported that various parts of the cocoa plant, e.g., cocoa beans (prepared as chocolate), the bark, flower, pulp, and leaf, and cocoa butter have been used for medicinal purposes. The phenolic compounds in cocoa contain bioactive compounds that have potential health benefits for chronic diseases such as inflammation, cardiovascular illness, neurodegenerative disorders, and cancer [17-19]. A naturally occurring cocoa-derived pentameric procyanidin (pentamer) caused G0/G1 arrest by selectively inhibiting the proliferation of human breast cancer cells (MDA-MB-231, MDA-MB-436, MDA-MB-468, SKBR-3, MCF-7) and benzo(a)pyrene-immortalized 184A1N4 and 184B5 cells [20]. The flavonols in cocoa exist as both monomeric flavonols, (-)-epicatechin, and to a much lesser extent, $(+)$-catechin, and are structurally related oligomers (procyanidins). Cocoa flavonols and procyanidins induced $70 \%$ growth inhibition with cell cycle blockade in Caco-2 cells at the G2/M phase [21].

Our objectives were to determine the antioxidant and antiproliferative activity of the methanolic extract of the following cocoa plant parts: leaf, bark, husk, fermented and unfermented shell, pith, root, and cherelle, against the estrogen receptor-positive (MCF-7) and estrogen receptor-negative 
(MDA-MB-231) breast cancer cell lines; liver (HepG2), colon (HT-29), lung (A549), and cervical (HeLa) cancer cell lines; and a normal liver cell line (WRL-68).

\section{Results and Discussion}

\subsection{Antioxidant Activity}

Free radicals are the primary cause of oxidative damage of biological molecules in the human body, and are related to coronary heart disease, aging, cancer, and dementia [22]. We used the 2,2-diphenyl2-picrylhydrazyl (DPPH) assay to determine the antioxidant activity of cocoa plant methanolic extracts, i.e., their ability to scavenge free radicals; concentrations of the extract and control enabling the scavenging of $50 \%$ of $300 \mu \mathrm{M}$ DPPH was detected. As shown in Table 1, the median effective concentrations $\left(\mathrm{EC}_{50}\right)$ of the leaf, bark, root, and cherelle extracts were $433.3 \pm 22.2,396.3 \pm 0.9$, $358.0 \pm 7.0$, and $390.0 \pm 7.0 \mu \mathrm{g} / \mathrm{mL}$, respectively. However, no $\mathrm{EC}_{50}$ values were obtained for the husk, fermented and unfermented shell, and pith extracts, as very low to no antioxidant activity was detected in these extracts. The root extract had the highest antioxidant activity among all the extracts $\left(\mathrm{EC}_{50}=358.0 \pm 7.0 \mu \mathrm{g} / \mathrm{mL}\right)$, which was significant $(p<0.05)$ among the root, leaf, and cherelle extracts, but no significant ( $p>0.05)$ with bark extract. A higher DPPH radical scavenging activity is associated with a lower $\mathrm{EC}_{50}$, and it was evident that the extracts could donate hydrogen to act as antioxidants [23]. We estimated the radical scavenging activity of the extracts by comparing the percentage scavenging activity of DPPH radical formation by the extracts to that of Trolox (positive control). Trolox had the highest antioxidant activity $\left(\mathrm{EC}_{50}=187.7 \pm 29.8 \mu \mathrm{g} / \mathrm{mL}, p<0.05\right)$ compared to the extracts because it is a pure antioxidant compound (Table 1). We detected varying levels of scavenging activity in the individual extracts, which we believe was due to the different mechanisms involved in the radical-antioxidant reaction [24].

Table 1. Antioxidant activity of cocoa plant part extracts.

\begin{tabular}{cc}
\hline Plant Part & $\mathbf{E C}_{\mathbf{5 0}}(\boldsymbol{\mu g} / \mathbf{m L}) *$ \\
\hline Leaf & $433.3 \pm 22.2^{\mathrm{d}}$ \\
Bark & $396.3 \pm 0.9^{\mathrm{a}}$ \\
Husk & - \\
Unfermented shell & - \\
Fermented shell & - \\
Pith & - \\
Root & $358.3 \pm 7.0^{\mathrm{a}, \mathrm{b}}$ \\
Cherelle & $390.0 \pm 7.0^{\mathrm{b}, \mathrm{c}}$ \\
Positive control (Trolox) & $187.7 \pm 29.8^{\mathrm{e}}$ \\
\hline
\end{tabular}

* Values are the means of three replicate samples $(n=3)$. Data are presented as the mean \pm SEM. Superscript letters indicate significant difference according to the Tukey honest significant difference test $(p<0.05)$.

\subsection{Total Phenolics Content}

Phenolic compounds are very important plant constituents because they exert antioxidant activity by inactivating lipid free radicals or by preventing hydroperoxide decomposition into free radicals. 
In this study, the total phenolic content of cocoa plant part methanolic extracts was measured in units of $\mathrm{g}$ gallic acid/100 $\mathrm{g}$ extract equivalent of phenolic compound (Table 2). The root extract had the highest total phenolic content $(22.0 \pm 1.1 \mathrm{~g} \mathrm{GAE} / 100 \mathrm{~g}$ extract $)$, followed by cherelle $(19.6 \pm 0.3 \mathrm{~g} / 100 \mathrm{~g}$ GAE $/ 100 \mathrm{~g}$ extract $)$, bark $(15.4 \pm 0.1 \mathrm{~g} \mathrm{GAE} / 100 \mathrm{~g}$ extract $)$, leaf $(13.3 \pm 0.2 \mathrm{~g}$ GAE/100 g extract $)$, husk $(8.7 \pm 0.4 \mathrm{~g}$ GAE/100 g extract), fermented shell $(4.3 \pm 0.3 \mathrm{~g}$ GAE/100 g extract), and unfermented shell $(1.5 \pm 0.1 \mathrm{~g}$ GAE$/ 100 \mathrm{~g}$ extract $)$; the pith extract had the lowest total phenolic content $(1.2 \pm 0.1 \mathrm{~g} \mathrm{GAE} / 100 \mathrm{~g}$ extract $)$.

Table 2. Total phenolic content of cocoa plant part extracts.

\begin{tabular}{cc}
\hline Plant Part & Total Phenolic Content * (g GAE/100 g Extract) \\
\hline Leaf & $13.3 \pm 0.2^{\mathrm{b}}$ \\
Bark & $15.4 \pm 0.1^{\mathrm{c}}$ \\
Husk & $8.7 \pm 0.4^{\mathrm{d}}$ \\
Unfermented shell & $1.5 \pm 0.1^{\mathrm{a}}$ \\
Fermented shell & $4.3 \pm 0.3^{\mathrm{e}}$ \\
Pith & $1.2 \pm 0.1^{\mathrm{a}}$ \\
Root & $22.0 \pm 1.1^{\mathrm{f}}$ \\
Cherelle & $19.6 \pm 0.3$ \\
\hline
\end{tabular}

* Values are means of three replicate samples $(n=3)$. Data are presented as the mean \pm SEM. Superscript letters indicate significant difference according to the Tukey honest significant difference test $(p<0.05)$. GAE, gallic acid equivalents.

The total phenolic content determined using the Folin-Ciocalteu method does not involve absolute measurements of the amounts of phenolic compounds, but are based on their chemical reducing capacity relative to gallic acid [25]. Many studies have reported that cocoa phenolics are bioactive compounds with potential health benefits for various chronic diseases, including inflammation, cardiovascular illness, neurodegenerative disorders, and cancer [19], and these activities might be related to their antioxidant activity [26]. Our findings indicate that the total phenolic content differs among different cocoa plant parts.

\subsection{Lipid Peroxidation Inhibition Activity}

In vitro lipid peroxidation inhibition activity was evaluated based on the determination of malondialdehyde (MDA) and related compounds in rat liver homogenate [27]. Thiobarbituric acid (TBA) reacts with MDA to form a diadduct, a pink chromogen, which can be detected at $532 \mathrm{~nm}$ using spectrophotometry. MDA is one of the major degradation products of lipid peroxidation and is studied widely as an index of lipid peroxidation, serving as an oxidative stress marker [28]. Lipid peroxidation is accelerated when free radicals are formed as a result of losing a hydrogen atom from the double bond in the unsaturated fatty acid structure. Free radical scavenging is a major antioxidation mechanism for inhibiting the lipid peroxidation chain reaction [29]; therefore, inhibiting lipid peroxidation is considered an important index of antioxidant activity. Table 3 describes the lipid peroxidation activity of the cocoa plant part methanolic extracts. The cherelle extract had weak activity, inducing $10.4 \% \pm 1.1 \%$ inhibition at the maximum concentration of $10 \mathrm{mg} / \mathrm{mL}$ compared to the Trolox standard of $32.6 \% \pm 3.2 \%$ inhibition, but no activity was observed for the leaf, bark, husk, 
unfermented and fermented shell, pith, and root extracts. The results suggest that these extracts had no anti-lipid activity due to the absence of excellent hydroxyl scavenging activity in the compounds in the methanolic extracts, which is significant for diseases caused by oxidative stress.

Table 3. Lipid peroxidation activity of cocoa plant part extracts.

\begin{tabular}{cc}
\hline Plant Part & Inhibition (\%) * \\
\hline Leaf & - \\
Bark & - \\
Husk & - \\
Unfermented shell & - \\
Fermented shell & - \\
Pith & - \\
Root & - \\
Cherelle & $10.4 \pm 1.1$ \\
Trolox (Positive control) & $32.6 \pm 3.2$ \\
\hline ans of three replicate samples $(n=3)$. Data are presented as the mean \pm SEM.
\end{tabular}

\subsection{Antiproliferative Activity}

A previous study reported that the $T$. cacao bean is a promising source of anti-cancer chemopreventive agents [30]. In the present study, the anti-cancer effect of methanolic extracts of cocoa plant parts against the human cancer cell lines A549, HeLa, HepG2, HT-29, MCF-7, and MDA-MB-231 were investigated. Based on the report by Atjanasuppat et al. the antiproliferative activities of the extracts were categorized according to the median inhibitory concentration ( $\mathrm{IC}_{50}$ ) into four groups: $\leq 20 \mu \mathrm{g} / \mathrm{mL}$, active; $>20-100 \mu \mathrm{g} / \mathrm{mL}$, moderately active; $>100-1000 \mu \mathrm{g} / \mathrm{mL}$, weakly active; and $>1000 \mu \mathrm{g} / \mathrm{mL}$, inactive [31]. The anti-cancer activities of the extracts were preliminarily screened by MTT assay, the percentage viability curves of treated cells were plotted against the extract concentrations, and the $\mathrm{IC}_{50}$ as compared to that of untreated cells was determined. According to the United States National Cancer Institute plant screening program, a crude extract is generally considered to have in vitro cytotoxic activity if the $\mathrm{IC}_{50}$ is $<30-40 \mu \mathrm{g} / \mathrm{mL}$ [32]. MTT screening of the antiproliferative activities of the extracts determined that the following extracts were moderately active (IC50 $<100 \mu \mathrm{g} / \mathrm{mL}$ ) against human cancer cell lines: leaf $(41.4 \pm 3.3 \mu \mathrm{g} / \mathrm{mL}$ against MCF-7 cells), bark $(72.0 \pm 9.3 \mu \mathrm{g} / \mathrm{mL}$ against MCF-7 cells), husk fermented shell $(71.4 \pm 12.11$ and $68.9 \pm 10.2 \mu \mathrm{g} / \mathrm{mL}$ against HeLa and HepG2 cells, respectively), root $(76.4 \pm 13.8 \mu \mathrm{g} / \mathrm{mL}$ against MCF-7 cells), and cherelle $(67.8 \pm 9.4$ and $68.9 \pm 11.4 \mu \mathrm{g} / \mathrm{mL}$ against HeLa and MCF-7 cells, respectively). The extracts that were weakly active against cancer cell lines $\left(\mathrm{IC}_{50}=100-1000 \mu \mathrm{g} / \mathrm{mL}\right)$ are listed in Table 4 . The leaf extract had the most potent anti-cancer activity against MCF-7 cells $\left(\mathrm{IC}_{50}=41.4 \pm 3.3 \mu \mathrm{g} / \mathrm{mL}\right.$ ) compared to the other extracts. Plants play an important role in medicine, and most anti-cancer constituents are from leaf extracts, for example, the leaves of Curcumin [33], Alnus sieboldiana [34], Hibiscus sabdariffa [35], Azadirachta indica [36], and Carpinus betulus [37]. Based on the IC50, the results in Table 4 show that all of the extracts had low activity against WRL-68 cells as compared to their activity against the cancer cells. The $\mathrm{IC}_{50}$ of the leaf extract against WRL-68 cells was $765.0 \pm 34.0 \mu \mathrm{g} / \mathrm{mL}$, higher than that against MCF-7 cells, which was $41.4 \pm 3.3 \mu \mathrm{g} / \mathrm{mL}$, suggesting that 
the cocoa leaf methanolic extract is more toxic against cancer cells than normal cells. Al-Rashidi et al. [38] noted that low toxicity towards normal cells and high toxicity towards cancer cells indicates that a plant extract has good anti-cancer constituents, and shows that the plant extract has a cytotoxic effect on cancer cells without causing toxicity in normal cells. The leaf extract was selected for further isolation and purification analysis using bioassay-guided fractionation, chromatography, and spectroscopy.

Table 4. Antiproliferative activity of cocoa plant part extracts.

\begin{tabular}{cccccccc}
\hline \multirow{2}{*}{ Plant Part } & \multicolumn{7}{c}{ IC $_{\mathbf{5 0}}(\boldsymbol{\mu g} / \mathbf{m L}) *$} \\
\cline { 2 - 8 } & A549 & HeLa & HepG2 & HT-29 & MCF-7 & MDA-MB-231 & WRL-68 \\
\hline Leaf & $541.3 \pm 69.8$ & $430.7 \pm 82.2$ & $493.3 \pm 17.2$ & $559.0 \pm 16.0$ & $41.4 \pm 3.3$ & $504.3 \pm 30.2$ & $765.00 \pm 34.0$ \\
Bark & $574.7 \pm 48.8$ & $688.7 \pm 64.8$ & $828.3 \pm 154.0$ & $468.7 \pm 22.2$ & $72.0 \pm 9.3$ & $555.3 \pm 36.2$ & $842.67 \pm 66.5$ \\
Husk & $533.7 \pm 63.5$ & $372.7 \pm 16.5$ & $396.0 \pm 40.4$ & $443.3 \pm 23.4$ & $62.2 \pm 14.9$ & $550.7 \pm 6.7$ & $792.33 \pm 75.5$ \\
Unfermented shell & $613.7 \pm 25.9$ & $468.3 \pm 36.0$ & $464.3 \pm 42.8$ & $163.0 \pm 18.6$ & $65.0 \pm 4.2$ & $555.0 \pm 10.1$ & $97.90 \pm 1.3$ \\
Fermented shell & $520.7 \pm 19.1$ & $71.4 \pm 12.1$ & $68.9 \pm 10.2$ & $197.0 \pm 13.2$ & $242.3 \pm 47.7$ & $486.3 \pm 13.0$ & $633.33 \pm 119.8$ \\
Pith & $595.0 \pm 82.6$ & $868.0 \pm 13.6$ & $951.0 \pm 13.8$ & $530.3 \pm 41.1$ & $329.7 \pm 52.7$ & $360.0 \pm 34.8$ & $489.00 \pm 50.6$ \\
Root & $636.3 \pm 66.4$ & $321.7 \pm 26.0$ & $237.3 \pm 19.0$ & $613.3 \pm 60.2$ & $76.4 \pm 13.8$ & $400.3 \pm 74.6$ & $>1000.0$ \\
Cherelle & $639.7 \pm 45.7$ & $67.8 \pm 9.4$ & $427.3 \pm 31.4$ & $629.3 \pm 37.8$ & $68.9 \pm 11.4$ & $614.7 \pm 11.3$ & $857.00 \pm 44.0$ \\
\hline
\end{tabular}

* Values are means of 3 replicate samples $(n=3)$. Data are presented as the mean \pm SEM.

\subsection{Correlation between Anti-Cancer Activity and Antioxidant Activity and Total Phenolic Content}

As many plant phenolic compounds are good sources of natural antioxidants [39], we determined the Pearson correlation coefficients between the antioxidant activity and total phenolic content of the extracts (Table 5). There was a strong significant relationship between antioxidant activity and total phenolic content (correlation coefficient, $\mathrm{r}=\sim 0.9, p<0.01$ ), indicating that high phenolic content is a significantly important factor for determining the antioxidant activity of cocoa plant part extracts. The antioxidant activity of cocoa co-products may be attributed to the phytochemical compounds they contain, especially the polyphenolic compounds, i.e., mainly flavan-3-ol compounds such as the monomers catechin and epicatechin and the dimer procyanidin B2. In addition to phenolic compounds, the presence of methylxanthine (theobromine and caffeine) and anthocyanins in cocoa beans might influence the antioxidant capacity. Recent studies have also demonstrated that the individual antioxidant activity of phenolic compounds in model systems have mutually synergistic or antagonistic effects $[40,41]$. In this study, the leaf extract displayed the strongest anti-cancer effect but moderate antioxidant activity and total phenolic content. This suggests that antioxidant activity and total phenolic content have a moderate effect on the anti-cancer activity of cocoa plant part extracts. The statistical analysis supported these results, where the anti-cancer activities of the extracts showed negative moderate correlation with their antioxidant activity $(r=-0.6)$ and total phenolic content $(\mathrm{r}=-0.6)$, but not significantly $(p>0.01)$ (Table 5). However, the inhibition of cancer cell proliferation by the extracts may not be wholly due to their polyphenolic content, but might be attributed to other bioactive compounds present. 
Table 5. Bivariate correlation of anti-cancer activities, antioxidant activity, and total phenolic content of cocoa plant part extracts.

\begin{tabular}{ccc}
\hline Relationship & Correlation Coefficient & $\boldsymbol{p}$ (2-Tailed) \\
\hline DPPH and total phenolic content & 0.872 & 0.005 \\
DPPH and anti-cancer activity (MCF-7 cells) & -0.563 & 0.146 \\
Total phenolic content and anti-cancer activity (MCF-7 cells) & -0.592 & 0.122 \\
\hline
\end{tabular}

Table 6. Phytochemical constituents of cocoa plant part extracts.

\begin{tabular}{cccccccccc}
\hline \multirow{2}{*}{ Compound } & \multicolumn{8}{c}{ Cocoa Plant Part Extracts } \\
\cline { 2 - 9 } & L & H & P & R & B & SF & SUF & C \\
\hline Alkaloids & - & - & - & - & - & - & - & - \\
Saponins & $1+$ & $1+$ & $1+$ & $1+$ & $2+$ & - & $1+$ & $1+$ \\
Flavonoids & $1+$ & $2+$ & - & - & - & $1+$ & - & $1+$ \\
Hydrolysable tannins & - & - & - & - & - & - & - & - \\
Condensed tannins & $2+$ & $1+$ & - & $2+$ & $2+$ & $1+$ & - & $2+$ \\
Triterpenes & $2+$ & - & - & - & - & - & - & - \\
Steroids & $2+$ & - & - & - & - & - & - & - \\
\hline
\end{tabular}

Note: For saponins: 1+, 1-2 cm froth; $2+, 2-3 \mathrm{~cm}$ froth; and $3+,>3 \mathrm{~cm}$ froth. For flavonoids, tannins, triterpenes, and steroids: $1+$, weak color; $2+$, mild color; $3+$, strong color. For alkaloids: - and $1+$, negligible amount of precipitate; $2+$, weak precipitate; $3+$, strong precipitate. L, leaf; H, husk; P, pith; R, root; B, bark; $\mathrm{SF}$, fermented shell; SUF, unfermented shell; C, cherelle.

\subsection{Phytochemical Testing}

We carried out preliminary phytochemical analysis for the presence of alkaloids, saponins, flavonoids, tannins, polyphenolics, steroids, and triterpenes, known to support bioactive activities in medicinal plants, in the extracts. Overall, saponins, flavonoids, condensed tannins, triterpenes, steroids were detected in the extracts, but not alkaloids or hydrolysable tannins (Table 6). Flavonoids, saponins, triterpenes, and tannins all have antioxidant and anti-cancer activity. The presence of these compounds is believed to contribute partly to their antiproliferative activity through antioxidant and free radical scavenging effects $[42,43]$. Tannins and polyphenolic compounds are useful for treating inflamed or ulcerated tissues, and have remarkable cancer prevention and anti-cancer activity $[44,45]$. Thus, cocoa leaf extract, which contained most of the abovementioned phytochemical constituents, may be a potential source of bioactive compounds for treating cancer. The leaf extract also contained steroids, which are very important compounds, especially given their relationship with compounds such as sex hormones. Steroids stimulate menstrual discharge and decrease milk secretion. Flavonoids, also among the leaf extract constituents, have a wide range of biological activities that include antimicrobial, anti-inflammatory, anti-angionic, analgesic, and anti-allergic effects, and cytostatic and antioxidant properties. The ability of flavonoids to scavenge hydroxyl radicals, superoxide anion radicals, and lipid peroxyl radicals, which is important for preventing diseases associated with oxidative damage of membranes, proteins, and DNA [44], highlights many of their health-promoting functions in living organisms. In the human diet, flavonoids may reduce the risk of various cancers as well as prevent menopausal symptoms. Furthermore, the leaf extract contained saponins, which have an inhibitory 
effect on inflammation, hypocholesterolemia, and diabetes [46]. However, the leaf extract did not contain alkaloids, which have been associated with medicinal uses for centuries, and of which one common bioactivity property is cytotoxicity; their absence in the cocoa plant tends to decrease the risk of poisoning by T. cacao [45].

\section{Experimental}

\subsection{Media, Chemicals, and Reagents}

Thiazolyl blue tetrazolium bromide (MTT), ( $($ )-6-hydroxy-2,5,7,8-tetramethylchroman-2-carboxylic acid (Trolox), Dulbecco's modified Eagle's medium (DMEM), DPPH, dimethyl sulfoxide (DMSO), Folin-Ciocalteu phenol reagent, gallic acid, trypan blue (0.4\%), ascorbic acid, TBA, ferric chloride $\left(\mathrm{FeCl}_{3}\right)$, Tris- $\mathrm{HCl}$, sodium carbonate anhydrous, and phosphate-buffered saline (PBS) were purchased from Sigma-Aldrich (St. Louis, MO, USA). Roswell Park Media Institute (RPMI) 1640, penicillin/streptomycin $(100 \times)$, trypsin-EDTA $(1 \times)$, and fetal bovine serum mycoplex (FBS) were obtained from PAA Laboratories, GmbH (Haidmannweg, Germany). The methanol (MeOH), n-butanol, and chloroform used were of the highest purity (Fisher Scientific, Loughborough, UK).

\subsection{Collection and Preparation of Plant Materials}

Fresh cocoa plant parts (leaf, bark, husk, unfermented and fermented shell, pith, root, cherelle) were collected from a cocoa smallholder field in Ranau, Sabah, Malaysia. Samples were collected during peak cocoa fruiting season in April and November. The cocoa plant parts were harvested, rinsed under tap water, air-dried, and then oven-dried at $40{ }^{\circ} \mathrm{C}$ for 5 days. Then, the samples were ground using a commercial blender. Each powdered plant part $(5 \mathrm{~g})$ was extracted by soaking in $200 \mathrm{~mL} \mathrm{MeOH}$ for 3 days at room temperature. The mixture was then filtered using a clean muslin cloth, followed by filter paper. The filtrate was then evaporated to dryness using a rotary evaporator attached to a vacuum pump. The extract was stored at $2-8{ }^{\circ} \mathrm{C}$ until used. To test the biological activity, dried crude extracts were dissolved in DMSO, and the stock solutions were later mixed with culture media (DMEM or RPMI 1640) to achieve concentrations of $1000,100,10,1,0.1,0.01$, and $0.001 \mu \mathrm{g} / \mathrm{mL}$ using 10 -fold serial dilutions.

\subsection{Cell Lines and Cell Culture Preparation}

The cell lines used in this study were estrogen receptor-positive (MCF-7) and estrogen receptor-negative (MDA-MB-231) breast cancer cells; liver (HepG2), colon carcinoma (HT-29), lung (A549), and cervical (HeLa) cancer cells; and normal human liver WRL-68 cells. MCF-7, HT-29, MDA-MB-231, and WRL-68 cells were cultured in 89\% DMEM with 10\% FBS and 1\% penicillin/streptomycin. HepG2, HeLa, and A549 cells were cultured in 89\% RPMI 1640 with 10\% FBS and $1 \%$ penicillin/streptomycin. All cells were cultured at $37{ }^{\circ} \mathrm{C}$ at $95 \%$ humidity and $5 \% \mathrm{CO}_{2}$ for 3 days until $80 \%-90 \%$ confluent. Subsequently, the spent medium was removed and replaced with fresh medium and incubated again for $24 \mathrm{~h}$. The cell cultures were then washed with PBS 1-2 times and were suspended using trypsin-EDTA. Fresh medium was added to the cells. 


\subsection{Determination of Antioxidant Activity}

The antioxidant activity of the extracts was assessed based on the radical scavenging effect of the stable DPPH free radical based on the method of Tyagi et al. [47] and using $300 \mu \mathrm{M} \mathrm{DPPH}$ in $\mathrm{MeOH}$. The extracts were dissolved in $\mathrm{MeOH}$, and each extract solution $(10 \mu \mathrm{L})$ was allowed to react with $200 \mu \mathrm{L} \mathrm{DPPH}$ at $37{ }^{\circ} \mathrm{C}$ for $30 \mathrm{~min}$ in a 96-well microtiter plate. After incubation, the decrease in absorbance (optical density, OD) of each solution was measured at $490 \mathrm{~nm}$ using a microplate reader. Trolox was used as the positive control. For each sample concentration tested, the percentage of DPPH was calculated using the following formula:

$$
\text { Antioxidant activity }(\%)=(\text { ODcontrol }- \text { ODsample }) / \text { ODcontrol } \times 100 \%
$$

where ODsample is the OD of the samples or positive control, and ODcontrol is the negative control OD. The values obtained were plotted against the sample concentration to determine the amount of antioxidant necessary to decrease the initial DPPH concentration by $50 \%\left(\mathrm{EC}_{50}\right)$. The antioxidant reaction kinetics in the presence of the extracts were compared with that of the reference Trolox. The assay was performed in triplicate.

\subsection{Determination of Total Phenolic Content}

The total phenolic content was determined according to the method of Ismail et al. [48] using the Folin-Ciocalteu reagent. Extracts $(100 \mu \mathrm{L}, 1 \mathrm{mg} / \mathrm{mL})$ were transferred to a test tube and $0.75 \mathrm{~mL}$ Folin-Ciocalteu reagent (previously diluted 10-fold with deionized water) was added and mixed. The mixture was allowed to stand at room temperature for $5 \mathrm{~min}$. Sodium carbonate $[0.75 \mathrm{~mL}, 6 \%$ $(\mathrm{w} / \mathrm{v})$ ] was added to the mixture and mixed gently. After standing at room temperature for $90 \mathrm{~min}$, the absorbance was read at $725 \mathrm{~nm}$ using a UV-Vis spectrophotometer. A standard calibration $(50-3000 \mathrm{mg} / \mathrm{mL})$ curve was plotted using gallic acid. The total phenolic content was expressed as gallic acid equivalents $(\mathrm{mg})$ per $100 \mathrm{~g}$ vegetable extract.

\subsection{Determination of Lipid Peroxidation Inhibition Activity}

The lipid peroxidation inhibition effect of cocoa plant parts was studied in vitro using the method of Sreelekshmi et al. [49] with some modifications. Rat liver tissue (2.0 g) was sliced and homogenized with $10 \mathrm{~mL} 15 \mathrm{mM} \mathrm{KCl-Tris-HCl}$ buffer ( $\mathrm{pH}$ 7.2). The reaction solution (3 replications) comprised $0.25 \mathrm{~mL}$ liver homogenate, $0.1 \mathrm{~mL}$ Tris-HCl buffer (pH 7.2), $0.05 \mathrm{~mL} 1 \mathrm{mM}$ ascorbic acid, $0.05 \mathrm{~mL}$ $4 \mathrm{mM} \mathrm{FeCl}_{3}$, and $0.05 \mathrm{~mL}$ extract $(1-0.156 \mathrm{mg} / \mathrm{mL})$ in each tube. The reaction tube was capped and incubated at $37{ }^{\circ} \mathrm{C}$ for $1 \mathrm{~h}$. Then, $0.5 \mathrm{~mL} 0.1 \mathrm{~N} \mathrm{HCl}, 0.2 \mathrm{~mL} \mathrm{9.8 \%} \mathrm{sodium} \mathrm{dodecyl} \mathrm{sulfate,} 0.9 \mathrm{~mL}$ distilled water, and $2 \mathrm{~mL} 0.6 \%$ TBA were added to each tube, which was vigorously shaken and placed in a boiling water bath at $100{ }^{\circ} \mathrm{C}$ for $30 \mathrm{~min}$. After cooling, the flocculent precipitate was removed by adding $5 \mathrm{~mL} n$-butanol, mixed well, and centrifuged at 9,000 rpm for $10 \mathrm{~min}$. The absorbance (Abs) of the supernatant was measured at $532 \mathrm{~nm}$ and the percentage of lipid peroxidation inhibition was determined as follows:

Lipid peroxidation inhibition $(\%)=($ Abs control - Abs sample $) /$ Abs control $\times 100 \%$ 


\subsection{Determination of Antiproliferative Activity}

The antiproliferative activity of the extracts against the human cancer cell lines was tested using the microtitration colorimetric method of MTT reduction [50] with minor modification. MTT is used to determine cell viability in cell proliferation and cytotoxicity assays. Exponential-phase cells that were $80 \%-90 \%$ confluent were harvested from maintenance cultures and counted using a hemocytometer with trypan blue solution. Cell suspensions $(100 \mu \mathrm{L})$ were dispensed in triplicate in 96-well culture plates at optimized concentrations of $\sim 1.0 \times 10^{5}$ cells $/ \mathrm{mL}$ per cancer cell line. After $24-\mathrm{h}$ incubation at $37^{\circ} \mathrm{C}, 100 \mu \mathrm{L}$ culture medium was removed from the wells and $100 \mu \mathrm{L}$ fresh medium containing the extracts $(1000,100,10,1,0.1,0.01,0.001 \mu \mathrm{g} / \mathrm{mL})$ was added to each well and incubated for another $48 \mathrm{~h}$. Wells containing DMEM or RPMI 1640 were used as the negative controls. At the end of the treatment period, the medium in each well was aspirated and replaced with $20 \mu \mathrm{L}$ of $5 \mathrm{mg}$ MTT working solution (MTT stock solution mixed with medium to attain a final concentration of $0.5 \mathrm{mg} / \mathrm{mL}$ ).

Briefly, MTT powder was dissolved in PBS to form an MTT stock solution $(5 \mathrm{mg} / \mathrm{mL})$. The stock solution was filter-sterilized through a $0.22 \mu \mathrm{m}$ filter and stored at $-20{ }^{\circ} \mathrm{C}$ until used. The cells were incubated at $37^{\circ} \mathrm{C}$ for $4 \mathrm{~h}$, and then the medium was aspirated and replaced with $100 \mu \mathrm{L}$ DMSO to dissolve the formazan crystals formed. The culture plates were shaken for $5 \mathrm{~min}$ and the absorbance (OD) of each well was read using an enzyme-linked immunosorbent assay reader at $570 \mathrm{~nm}$ (reference wavelength $=630 \mathrm{~nm}$ ). The percentage of antiproliferative activity compared to that of untreated cells was determined as follows:

$$
\text { Cell viability }(\%)=(\text { ODsample }- \text { ODblank }) /(\text { ODcontrol }- \text { ODblank }) \times 100 \%
$$

where ODsample is the absorbance of the samples, ODblank the absorbance of the blank (of the respective concentration solutions), and ODcontrol the absorbance of the control wells. The results were produced from three independent experiments, and each experiment was performed in triplicate. The relative viability of the treated cells compared to that of the control cells is expressed as $\%$ cell viability.

\subsection{Phytochemical Analysis}

Preliminary phytochemical analysis of the plant extracts was performed using standard procedures. About $5.0 \mathrm{~g}$ dried powdered material was analyzed for the presence of phytochemical constituents that usually have biological activities, i.e., alkaloids, flavonoids, saponins, tannins, triterpenes, and steroids. For alkaloid testing, samples were extracted with chloroform, followed by the addition of ammoniacal chloroform. The mixture was then treated with $10 \%$ sulphuric acid and tested with Mayer's reagent. The formation of white precipitate indicated the presence of alkaloids. For flavonoid testing, samples were extracted with chloroform, dissolved in ether, and shaken in $10 \%$ ammonia solution. The formation of a yellow color in the ammonia layer indicated the presence of flavonoids. For saponin testing, samples were extracted in $\mathrm{MeOH}$ and mixed with distilled water in a test tube. The formation of a stable froth persisting for at least $15 \mathrm{~min}$ indicated the presence of saponins. For tannin testing, samples were extracted in $\mathrm{MeOH}$ and mixed with $1 \% \mathrm{FeCl}_{3}$ solution. The formation of a blue-black color indicated the presence of hydrolysable tannins, while a brownish-green color indicated condensed tannins. For triterpene and steroid testing, samples were extracted with chloroform and 
were tested using the Liebermann-Burchard reagent. The formation of a reddish color indicated the presence of triterpenes; a greenish color indicated steroids. All samples were analyzed at the Laboratory of Phytomedicine, Forest Research Institute of Malaysia, Kepong, Malaysia.

\subsection{Statistical Analysis}

All data are expressed as the mean \pm SEM. The free radical scavenging activity values and total phenolic content of the samples were analyzed using 1-way analysis of variance with SPSS version 16.0-2007 software (IBM Corporation, Armonk, NY, USA) using the Tukey honest significant difference test to determine the difference between samples and controls. The MTT assays for each sample were carried out in triplicate on 3 different days. The $\mathrm{IC}_{50}$ values were calculated using GraphPad Prism version 5.02-2008 software (GraphPad Software, Inc., La Jolla, CA, USA). Pearson's correlation coefficient test was used to assess correlations between means. Differences were considered significant at $p<0.05$.

\section{Conclusions}

We successfully screened the antioxidant and antiproliferative activities of $T$. cacao leaf, bark, husk, unfermented and fermented shell, pith, root, and cherelle methanolic extracts. The root extract has the highest antioxidant activity and total phenolic content compared to the other extracts. However, only the cherelle extract inhibits lipid peroxidation activity. The leaf extract appears to have high potential antiproliferative effects. Linear regression analysis revealed a positive strong correlation between antioxidant activity and total phenolic content, but negative moderate correlation between antioxidant activity and total phenolic content and anti-cancer effect. Future studies will evaluate and investigate the action of T. cacao leaf extract against MCF-7 breast cancer cells in greater detail and identify the possible bioactive compounds that contribute to the anti-cancer activity of the extract.

\section{Acknowledgments}

The authors would like to thank the Malaysian Cocoa Board (MCB) and the cocoa smallholders of Sabah for identifying and supplying plant specimens, and the Universiti Putra Malaysia (UPM) Department of Biomedical Sciences for providing the human cancer cell lines and laboratory facilities. This work was funded by the MCB Temporary Research Fund and UPM Research University Grant Scheme (9302400). The authors also would like to thank Hazirah Abdul Radzak and Siti Sarah Sazali for their assistance.

\section{Author Contributions}

Conceived and designed the experiments: Z.B., A.M.A., Y.H.T.Y., and R.A.H. Performed the experiments: Z.B. Analyzed the data: Z.B., A.M.A., Y.H.T.Y., and R.A.H. Contributed reagents/materials/analysis tools: A.M.A. and R.K. Wrote the paper: Z.B. 


\section{Conflicts of Interest}

The authors declare no conflict of interest.

\section{References}

1. Giri, B.; Gomes, A.; Debnath, A.; Saha, A.; Biswas, A.K.; Dasgupta, S.C. Antiproliferative, cytotoxic and apoptogenic activity of Indian toad (Bufo melanostictus, Schneider) skin extract on U937 and K562 cells. Toxicon 2006, 48, 388-400.

2. Mbaveng, A.T.; Kuete, V.; Mapunya, B.M.; Beng, V.P.; Nkengfack, A.E.; Meyer, J.J.M.; Lall, N. Evaluation of four Cameroonian medicinal plants for anticancer, antigonorrheal and antireverse transcriptase activities. Environ. Toxicol. Pharmacol. 2011, 32, 162-167.

3. Abdul, A.B.; Abdelwahab, S.I.; Fong, H.K.; Mohan, S.M.; Al-Zubairi, A.S.; Elhassan, M.M. In vitro response of cancer cells to the growth-inhibitory effects of dichloromethane extract of Goniothalamus umbrosus. Res. J. Pharmacol. 2009, 3, 1-6.

4. Burstein, H.J.; Schwartz, R.S. Molecular origins of cancer. N. Engl. J. Med. 2008, 358, 527.

5. Rajesh, R.; Chitra, K.; Paarakh, P.M.; Chidambaranathan, N. Anticancer activity of aerial parts of Aerva lanata Linn Juss ex Schult against Dalton's Ascitic Lymphoma. Eur. J. Integr. Med. 2011, 3, e245-e250.

6. Nurhanan, M.Y.; Asiah, O.; Mohd Ilham, M.A.; Siti Syarifah, M.M.; Norhayati, I.; Lili Sahira, H. Anti-proliferative activities of 32 Malaysian plant species in breast cancer cell lines. J. Trop. For. Sci. 2008, 20, 77-81.

7. Conforti, F.; Ioele, G.; Statti, G.A.; Marrelli, M.; Ragno, G.; Menichini, F. Antiproliferative activity against human tumor cell lines and toxicity test on Mediterranean dietary plants. Food Chem. Toxicol. 2008, 46, 3325-3332.

8. Jain, R.; Jain, S.K. Screening of in vitro cytotoxic activity of some medicinal plants used traditionally to treat cancer in Chhattisgarh state, India. Asian Pac. J. Trop. Biomed. 2011, 1, S147-S150.

9. Sharma, J.V.C.; Pitchaiah, G.; Satyavati, D.; Rao, J.V.; Sanjay, H. In vitro anticancer activity of methanolic extract of roots of Glochidion zeylanicum (Gaertn.). Int. J. Res. Pharm. Biomed. Sci. 2011, 2, 760-764.

10. Shoeb, M. Minireview anticancer agents from medicinal plants. Bangladesh J. Pharmacol. 2006, $1,35-41$.

11. Nisa, S.; Bibi, Y.; Waheed, A.; Zia, M.; Sarwar, S.; Ahmed, S.; Chaudhary, M.F. Evaluation of anticancer activity of Debregeasia Salicifolia extract against estrogen receptor positive cell line. Afr. J. Biotechnol. 2011, 10, 990-995.

12. Caamal-Fuentes, E.; Torres-Tapia, L.W.; Simá-Polanco, P.; Peraza-Sánchez, S.R.; Moo-Puc, R. Screening of plants used in Mayan traditional medicine to treat cancer-like symptoms. J. Ethnopharmacol. 2011, 135, 719-724.

13. Ramiro, E.; Franch, À.; Castellote, C.; Andrés-Lacueva, C.; Izquierdo-Pulido, M.; Castell, M. Effect of Theobroma cacao flavonoids on immune activation of a lymphoid cell line. Br. J. Nutr. 2007, 93, 859-866. 
14. Jalil, A.M.M.; Ismail, A.; Pei, C.P.; Hamid, M.; Kamaruddin, S.H.S. Effects of cocoa extract on glucometabolism, oxidative stress, and antioxidant enzymes in obese-diabetic (Ob-db) rats. J. Agric. Food Chem. 2008, 56, 7877-7884.

15. Addai, F.K. Natural cocoa as diet-mediated antimalarial prophylaxis. Med. Hypotheses 2010, 74, 825-830.

16. Jalil, A.M.M.; Ismail, A. Polyphenols in cocoa and cocoa products: Is there a link between antioxidant properties and health? Molecules 2008, 13, 2190-2219.

17. Schinella, G.; Mosca, S.; Cienfuegos-Jovellanos, E.; Pasamar, M.Á.; Muguerza, B.; Ramón, D.; Ríos, J.L. Antioxidant properties of polyphenol-rich cocoa products industrially processed. Food Res. Int. 2010, 43, 1614-1623.

18. Rimbach, G.; Melchin, M.; Moehring, J.; Wagner, A.E. Polyphenols from cocoa and vascular health-a critical review. Int. J. Mol. Sci. 2009, 10, 4290-4309.

19. Arlorio, M.; Bottini, C.; Travaglia, F.; Locatelli, M.; Bordiga, M.; Coïsson, J.D.; Martelli, A.; Tessitore, L. Protective activity of Theobroma cacao L. phenolic extract on AML12 and MLP29 liver cells by preventing apoptosis and inducing autophagy. J. Agric. Food Chem. 2009, 57, 10612-10618.

20. Ramljak, D.; Romanczyk, L.J.; Metheny-Barlow, L.J.; Thompson, N.; Knezevic, V.; Galperin, M.; Ramesh, A.; Dickson, R.B. Pentameric procyanidin from Theobroma cacao selectively inhibits growth of human breast cancer cells. Mol. Cancer Ther. 2005, 4, 537-546.

21. Kim, M.; Wu, X.; Song, I.; Fu, M.; Chang, S.-H.; Lisanti, M.P.; Pestell, R. Selective cytotoxicity of synthesized procyanidin 3-O-galloylepicatechin-4b, 8-3-O-galloylcatechin to human cancer cells. Cell Cycle 2008, 7, 1648-1657.

22. $\mathrm{Hu}, \mathrm{W}$.; Yu, L.; Wang, M.-H. Antioxidant and antiproliferative properties of water extract from Mahonia bealei (Fort.) Carr. leaves. Food Chem. Toxicol. 2011, 49, 799-806.

23. Ozsoy, N.; Can, A.; Yanardag, R.; Akev, N. Antioxidant activity of Smilax excelsa L. leaf extracts. Food Chem. 2008, 110, 571-583.

24. Althunibat, O.Y.; Hashim, R.B.; Taher, M.; Daud, J.M.; Ikeda, M.-A.; Zali, B.I. In vitro antioxidant and antiproliferative activities of three Malaysian sea cucumber species. Eur. J. Sci. Res. 2009, 37, 376-387.

25. Hossain, M.A.; Shah, M.D.; Gnanaraj, C.; Iqbal, M. In vitro total phenolics, flavonoids contents and antioxidant activity of essential oil, various organic extracts from the leaves of tropical medicinal plant tetrastigma from Sabah. Asian Pac. J. Trop. Med. 2011, 4, 717-721.

26. Li, H.-B.; Wong, C.-C.; Cheng, K.-W.; Chen, F. Antioxidant properties in vitro and total phenolic contents in methanol extracts from medicinal plants. LWT-Food Sci. Technol. 2008, 41, 385-390.

27. Nagmoti, D.M.; Khatri, D.K.; Juvekar, P.R.; Juvekar, A.R. Antioxidant activity and free radical-scavenging potential of Pithecellobium dulce Benth seed extracts. Free Radic. Antioxid. 2012, 2, 37-43.

28. Prasad, K.N.; Hao, J.; Shi, J.; Liu, T.; Li, J.; Wei, X.; Qiu, S.; Xue, S.; Jiang, Y. Antioxidant and anticancer activities of high pressure-assisted extract of longan (Dimocarpus longan Lour.) fruit pericarp. Innov. Food Sci. Emerg. Technol. 2009, 10, 413-419. 
29. Fu, W.; Chen, J.; Cai, Y.; Lei, Y.; Chen, L.; Pei, L.; Zhou, D.; Lang, X.; Ruan, J. Antioxidant, free radical scavenging, anti-inflammatory and hepatoprotective potential of the extract from Parathelypteris nipponica (Franch. et Sav.) Ching. J. Ethnopharmacol. 2010, 130, 521-528.

30. Hazirah, A.; Zainal, B.; Abdah, M. Total phenolic content, antioxidant and cytotoxic activity of cocoa (Theobroma cacao L.) polyphenols extracts on cancer cell lines. Malays. J. Nutr. 2013, 19, 223-232.

31. Atjanasuppat, K.; Wongkham, W.; Meepowpan, P.; Kittakoop, P.; Sobhon, P.; Bartlett, A.; Whitfield, P.J. In vitro screening for anthelmintic and antitumour activity of ethnomedicinal plants from Thailand. J. Ethnopharmacol. 2009, 123, 475-482.

32. Oskoueian, E.; Abdullah, N.; Saad, W.Z.; Omar, A.R.; Kuan, W.B.; Zolkifli, N.A.; Hendra, R.; Ho, Y.W. Antioxidant, anti-inflammatory and anticancer activities of methanolic extracts from Jatropha curcas Linn. J. Med. Plants Res. 2011, 5, 49-57.

33. Prasanna, R.; Harish, C.C.; Pichai, R.; Sakthisekaran, D.; Gunasekaran, P. Anti-cancer effect of Cassia auriculata leaf extract in vitro through cell cycle arrest and induction of apoptosis in human breast and larynx cancer cell lines. Cell Biol. Int. 2009, 33, 127-134.

34. Ludwiczuk, A.; Saha, A.; Kuzuhara, T.; Asakawa, Y. Bioactivity guided isolation of anticancer constituents from leaves of Alnus sieboldiana (Betulaceae). Phytomedicine 2011, 18, 491-498.

35. Lin, H.-H.; Chan, K.-C.; Sheu, J.-Y.; Hsuan, S.-W.; Wang, C.-J.; Chen, J.-H. Hibiscus sabdariffa leaf induces apoptosis of human prostate cancer cells in vitro and in vivo. Food Chem. 2012, 132, 880-891.

36. Elumalai, P.; Gunadharini, D.N.; Senthilkumar, K.; Banudevi, S.; Arunkumar, R.; Benson, C.S.; Sharmila, G.; Arunakaran, J. Ethanolic neem (Azadirachta indica A. Juss) leaf extract induces apoptosis and inhibits the IGF signaling pathway in breast cancer cell lines. Biomed. Prev. Nutr. 2012, 2, 59-68.

37. Cieckiewicz, E.; Angenot, L.; Gras, T.; Kiss, R.; Frédérich, M. Potential anticancer activity of young Carpinus betulus leaves. Phytomedicine 2012, 19, 278-283.

38. Al-Rashidi, W.; Mat Supri, N.N.; Manshoor, N. Cytotoxic activity of crude extract from Costus malortieanus (Costaceae). Am.-Eurasian J. Toxicol. Sci. 2011, 3, 63-66.

39. Wangcharoen, W.; Morasuk, W. Antioxidant capacity and phenolic content of chilies. Kasetsart J. Nat. Sci. 2007, 41, 561-569.

40. Martínez, R.; Torres, P.; Meneses, M.A.; Figueroa, J.G.; Pérez-Álvarez, J.A.; Viuda-Martos, M. Chemical, technological and in vitro antioxidant properties of cocoa (Theobroma cacao L.) co-products. Food Res. Int. 2012, 49, 39-45.

41. Othman, A.; Ismail, A.; Abdul Ghani, N.; Adenan, I. Antioxidant capacity and phenolic content of cocoa beans. Food Chem. 2007, 100, 1523-1530.

42. Mithraja, M.J.; Antonisamy, J.M.; Mahesh, M.; Paul, Z.M.; Jeeva, S. Phytochemical studies on Azolla pinnata R. Br., Marsilea minuta L. and Salvinia molesta Mitch. Asian Pac. J. Trop. Biomed. 2011, 1, S26-S29.

43. Zakaria, Z.A.; Rofiee, M.S.; Mohamed, A.M.; Teh, L.K.; Salleh, M.Z. In vitro antiproliferative and antioxidant activities and total phenolic contents of the extracts of Melastoma malabathricum leaves. J. Acupunct. Meridian Stud. 2011, 4, 248-256. 
44. Aiyegoro, O.A.; Okoh, A.I. Phytochemical screening and polyphenolic antioxidant activity of aqueous crude leaf extract of Helichrysum pedunculatum. Int. J. Mol. Sci. 2009, 10, 4990-5001.

45. Aiyegoro, O.A.; Okoh, A.I. Preliminary phytochemical screening and in vitro antioxidant activities of the aqueous extract of Helichrysum longifolium DC. BMC Complement. Altern. Med. 2010, 10, 21.

46. Kusuma, I.W.; Kuspradini, H.; Arung, E.T.; Aryani, F.; Min, Y.-H.; Kim, J.-S.; Kim, Y. Biological activity and phytochemical analysis of three Indonesian medicinal plants, Murraya koenigii, Syzygium polyanthum and Zingiber purpurea. J. Acupunct. Meridian Stud. 2011, 4, 75-79.

47. Tyagi, S.N.; Saxena, A.; Patel, B.D. In vitro Antioxidant Activity of methanolic and aqueous extract of Flacourtia indica Merr. Am.-Eurasian J. Sci. Res. 2010, 5, 201-206.

48. Ismail, A.; Marjan, Z.; Foong, C. Total antioxidant activity and phenolic content in selected vegetables. Food Chem. 2004, 87, 581-586.

49. Sreelekshmi, R.; Latha, P.G.; Arafat, M.M.; Shyamal, S.; Shine, V.J.; Anuja, G.I.; Suja, S.R.; Rajasekharan, S. Anti-inflammatory, analgesic and anti-lipid peroxidation studies on stem bark of Ficus religiosa Linn. Nat. Prod. Radiance 2007, 6, 377-381.

50. Akim, A.; Ling, L.C.; Rahmat, A.; Zakaria, Z.A. Antioxidant and anti-proliferative activities of roselle juice on Caov-3, MCF-7, MDA-MB-231 and HeLa cancer cell lines. Afr. J. Pharm. Pharmacol. 2011, 5, 957-965.

Sample Availability: Samples of the cocoa plant extracts are available from the authors.

(C) 2014 by the authors; licensee MDPI, Basel, Switzerland. This article is an open access article distributed under the terms and conditions of the Creative Commons Attribution license (http://creativecommons.org/licenses/by/4.0/). 